\title{
Empirical Study of Relationship between Money Supply and Inflation Based on Data from New Standardised Reporting Format
}

\author{
Satrugan $\operatorname{Sinah}^{1}$ \\ ${ }^{1}$ School of Management, University of Science \& Technology of China, Hefei, China \\ Correspondence: Satrugan Sinah, School of Management, University of Science \& Technology of China, 96 \\ Jinzhai Road, Hefei, 230026 Anhui, China. Tel: 86-131-2757-1351. E-mail: sinah_satrugan@yahoo.com
}

Received: December 4, 2017

Accepted: December 16, 2017

Online Published: December 20, 2017

doi:10.5539/ijef.v10n1p213

URL: https://doi.org/10.5539/ijef.v10n1p213

\begin{abstract}
This study is based on data obtained from the new standardised reporting format introduced by International Monetary Fund. The empirical estimation of relationship between money supply and inflation leads to development of a model, which can be used by policy makers while formulating monetary policy. This model is based on new standardised reporting format, which has a broader approach in terms of capturing monetary aggregates in a country. Thus, as opposed to findings of many earlier studies, which used non-standardised data, this paper shows that an increase in money supply leads to an increase in consumer price index.
\end{abstract}

Keywords: money supply, inflation, SRF, broad money, domestic credit

\section{Introduction}

Money supply is the amount of money available in a country. Domestic credit is one of the factors, which leads to changes in amount of money. The measurement of money supply is done by looking at amount of domestic credit and net foreign assets in a country. Money supply is categorised as narrow money and quasi money. The definition of money supply differs from country to country. This is because it depends on what is added by country to ascertain total money.

Notably, one of the important objective of central banks is to control money supply. In executing this objective, central banks monitor the stock of broad money in a country. An increase in money supply is acceptable but significant increase in money supply would indicate that other economic problems and issues are brewing up, which central banks will have to deal with in future.

One of the problems associated with increase in money supply is inflation. According to Vaish (2002), inflation is a sustained rise in general price level brought about by high rate of expansion in aggregate money supply. With increase in money supply, individuals will have more on their hands and they will demand more goods. This will lead to demand pull inflation. Hence, central banks need to control money supply to avoid getting trapped in situations of excessive inflation rate.

However, at the same time a country needs to ensure that it does not ends up into deflation or zero rate of inflation. Both of these scenarios are not healthy for a country.

A zero inflation is a situation where price of goods remains unchanged, a situation before deflation. With no increase in price of goods and services, the consumers are likely to me more satisfied. However, this situation will prevail only in short-run, whereby consumers will get all those goods which they need at low price.

In long run, the business firms will realise that without increase in price, they are not able to make profit and their business is unsustainable. Firms will not find it worth carrying on business when at the end of the day, the entrepreneurs and owners have to go home without any profit in their pocket. As a result, these businesses will shut down and this will lead to unemployment as well. Consumers will also get worse-off as they will no longer be able to purchase goods that conveniently now. The consumers will have to choose from limited number of shops, which may remain in business. However, with zero inflation rate, the remaining firms will also carry a risk of shutting down.

Notably, with zero inflation rate, firms will not be left with enough money for investment and growth. Lack of new investment means that the country will not be seeing creation of new job opportunities. Unemployment rate 
will continue to rise and this will get amplified further when those existing firms will also shut down due to lack of profit.

The trade-off between unemployment and inflation was explained by Phillips (1958). This relation is depicted by Phillips Curve in Figure 1. In short-run, a country needs to choose either to have higher inflation and less unemployment or low inflation and high unemployment. So having some inflation in a country is a trade-off for unemployment problem in short-run.

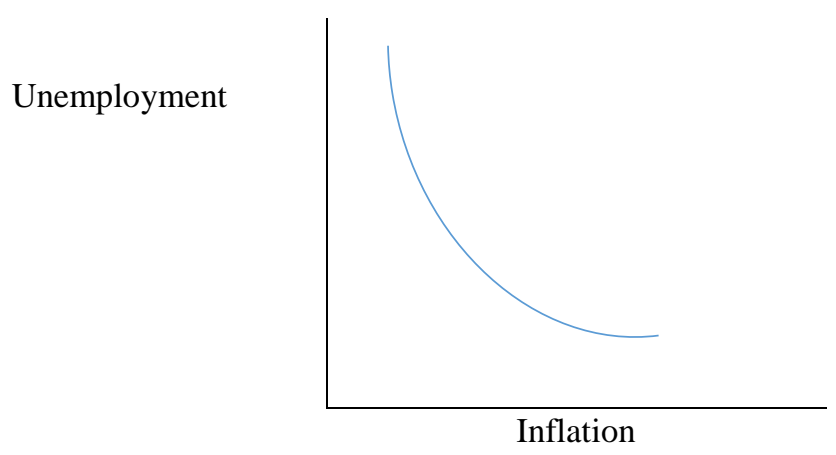

Figure 1. Phillips curve (1958)

Hence, in light of role which money supply and inflation plays in formulation of monetary policy, this paper would use data from new standardised reporting format introduced by International Monetary Fund (IMF) to model relationship between money supply and inflation. The first part of this research looks into existing literature on money supply and inflation, while the second section looks into data, methodology and theoretical aspects of this study. In third section, there is a thorough analysis and discussion of empirical findings for development of money supply and inflation model. The last section of this paper concludes the paper with findings from new standardised reporting format.

\section{Literature Review}

Notably, a number of literature exist on money supply and inflation. However, all these studies used non-standardised sets of data to study money supply and inflation. Prior to introduction of Standard Reporting Format (SRF) by IMF, the central banks reported monetary and financial data using non-standardised reporting format.

The compilation of data in Standardised Reporting Format was first published in Monetary and Financial Statistics Manual by IMF in September 2006 (International Monetary Fund, 2016). A number of revisions and amendments were done to include more sectors in financial statistics and it was not until 2008 that this was finalised. In addition to this, the IMF also introduced a new Government Financial Statistics Manual in 2014 to capture more sectors in reporting of national statistics. These surveys led to changes in the way the central banks and government collected and reported financial statistics. New reporting formats are more detailed and the definitions provided has wide coverage of financial sectors. Thus, in terms of this paper, data used from SRF has a wide coverage, which is anticipated to provide a more realistic view of broad money and inflation data in a country.

A study by Mohammad et al. (2009) on Pakistan showed a negative relationship between money supply and inflation. They used non-standardised data from 1977 to 2000. Similarly, Gatawa et al. (2013) studied the relationship between money supply and inflation in Nigeria using data from 1973-2013. The findings revealed that money supply and inflation are negatively related.

Moreover, Shostak (2017) used 1960 onward data for 47 countries and found that high money supply does not lead to inflation. This indicates a negative relationship between money supply and inflation.

Gokal and Hanif (2004) looked into the relationship between money supply and inflation in Fiji. Their tests revealed that a negative correlation exists between inflation and money supply. Koti and Bixho (2016) did a similar study on Albania and concluded that money supply has a negative sign towards inflation.

However, some other researchers were able to find existence of positive relationship between money supply and inflation. Vladova and Yanchev (2015) found evidence of one-way relationship between money supply and 
inflation in Bulgaria. This relationship was even stronger with core inflation.

Strano (n.d) studied money and inflation relationship in Iceland together with a sample of 11 countries. In this study, it was found that money and inflation are positively related. Similary, Mbongo et al. (2014) looked into inflation rate and money supply of Tanzania and found that money supply has significant impact on inflation. It was suggested that central banks need to keep a tight monetary policy to control inflation.

Denbel (2016) studied the relationship between money supply, economic growth and inflation in Ethopia. From this study, it was concluded that inflation is a monetary policy phenomena and Central Bank needs to look into money supply to control inflation in Ethopia. Amin (2011) had similar findings in his study. Amin (2011) studied "Quantity Theory of Money and its Applicability" in the case of Bangladesh using Johansen cointegration method. The empirical findings indicated the existence of long run cointegrating relationship between money supply and inflation.

Osakwe (1983) attempted to verify the amount of government expenditure that affected money supply in the ten-year period 1970-1980 by using quarterly data. Significant statistical evidence obtained from the analysis showed strong relationships between increases in net current expenditure and growth in money supply, and growth in money supply and inflation, on the other.

\section{Data \& Methodology}

To study the relationship between money supply and inflation, we need to first have a good understanding of quantity theory of money. The quantity theory of money explains that the amount of money supply (M) multiply by number of times money changes hand $(\mathrm{V})$, is equal to price of goods $(\mathrm{P})$ multiply by quantity of goods $(\mathrm{Q})$.

$$
M V=P Q
$$

The right hand side of the equation $P Q$ is rather a total spending in an economy. Total spending in an economy also equates to Gross Domestic Product (GDP). Thus, this equation can also be written as:

$$
M V=G D P
$$

With this understanding and knowing some of these variables, we now know that the quantity theory of money equation can be used to calculate money supply by making $M$ the subject of the formula:

$$
M=G D P / V
$$

This will give us the amount of money supply in a country, which can be used together with inflation data to analyse further whether increase in money supply leads to increase in inflation rate.

An alternative to above method would be adding Domestic Credit (DC) and Net Foreign Assets (NFA) to obtain total money supply. This is because we understand that overall credit and amount of money coming into the country from abroad makes up broad money, which is money supply. After adding domestic credit and net foreign assets, we need to remember to subtract Other Items Net (OIN), which are not counted as money supply. Based on this logic, we derive the following formula for calculation of money supply:

$$
B M=D C+N F A-O I N
$$

Notably, Fiji is one of the countries which adopted SRF as it was rolled out by IMF in 2008. Hence, we will use SRF data from Fiji to model relationship between money supply and inflation.

In above equation (4), domestic credit should capture credits given by all lending institutions in a country, so that we are able to get a more precise count of money supply. In case of Fiji, prior to implementation of SRF, domestic credit captured credits given by commercial banks and three other non-bank financial institutions. This excluded many other non-bank financial institutions and players in financial market, which all were licensed to extend credit. The implementation of SRF by International Monetary Fund in 2008 led to new surveys, such as Central Bank, Depository Corporation, Other Depository Corporation, Other Financial Corporation and Financial Corporation Surveys. This captures financial data more broadly and with greater precision, as opposed to earlier era when Fiji had only central bank and depository corporations' surveys. These two surveys limited calculation of domestic credit only from major commercial banks and central bank.

Thus, we obtain data on domestic credit from the new financial corporations' survey, which provides a broader picture of overall credit in an economy and thus a more precise measure of money supply.

The other element, which adds to overall money supply is Net Foreign Assets. This is calculated by looking at Total Foreign Assets minus Total Foreign Liabilities. Now with availability of SRF, the net foreign assets figure is also obtained from the financial corporations' survey. This gives a broader view of money supply by capturing foreign assets and foreign liabilities from all financial player's balance sheets. 
The inflow of foreign reserves increases money supply and central bank will control this through sterilisation, in cases of fixed exchange rate regime (Sinah, 2017). Sterilisation will take place in form of central bank absorbing money supply by issuing treasury bills or other papers at interest rate agreed in money market. The payment of interest rate adds to monetary policy cost borne by central banks.

The Other Items Net are assets not included in counting of money supply less liabilities not included in money supply. Example of such items include equity of reporting institution, interbank positions and any other non-financial assets in balance sheet.

Thus, the combination of domestic credit, net foreign assets less other items net gives the total money supply. As mentioned earlier, the definition of money supply varies from country to country. This definition is primarily based on items included in money supply to add to overall broad money.

We will look at case of Fiji to study items that builds into broad money under SRF (Table 1).

Table 1. Broad money in standardised reporting format

\begin{tabular}{l}
\hline Components of Broad Money \\
\hline Currency Outside Depository Corporations \\
Currency Issued by Central Government \\
Transferable Deposits \\
Other Deposits \\
Securities other than Shares \\
Deposits in Non-financial Corporations \\
Securities Issued by Central Government \\
\hline
\end{tabular}

Adding the above list of items in SRF will give total amount of money supply in a country. Increase in any of these elements would lead to an increase in money supply.

Currency outside Depository Corporation and currency issued by central government will provide the amount of currency in circulation. Transferable deposits are demand and savings deposits, while other deposit refers to time deposit.

Under the new reporting format, securities other than shares and securities issued by government is also counted as broad money. This captures more items and thus measures money supply with greater perfection than what the central banks use to report under non-standardised reporting format.

Thus, we will use data from new standardised reporting format to study money supply and inflation. First we obtained monthly data from International Financial Statistics on broad money and inflation rate from 1973 to 2016 (International Monetary Fund, 2016). This large set of data allows for study of patterns of movement.

\section{Results \& Discussion}

We plotted the annual percentage change in broad money and annual inflation rate data together in order to observe the pattern of movement in these two variables. As per Figure 2, it can be seen that there are consistencies in movement of money supply and inflation rate. Increase in money supply also leads to spike in inflation rate. This shows that there is a pattern in movement of money supply and inflation rate.

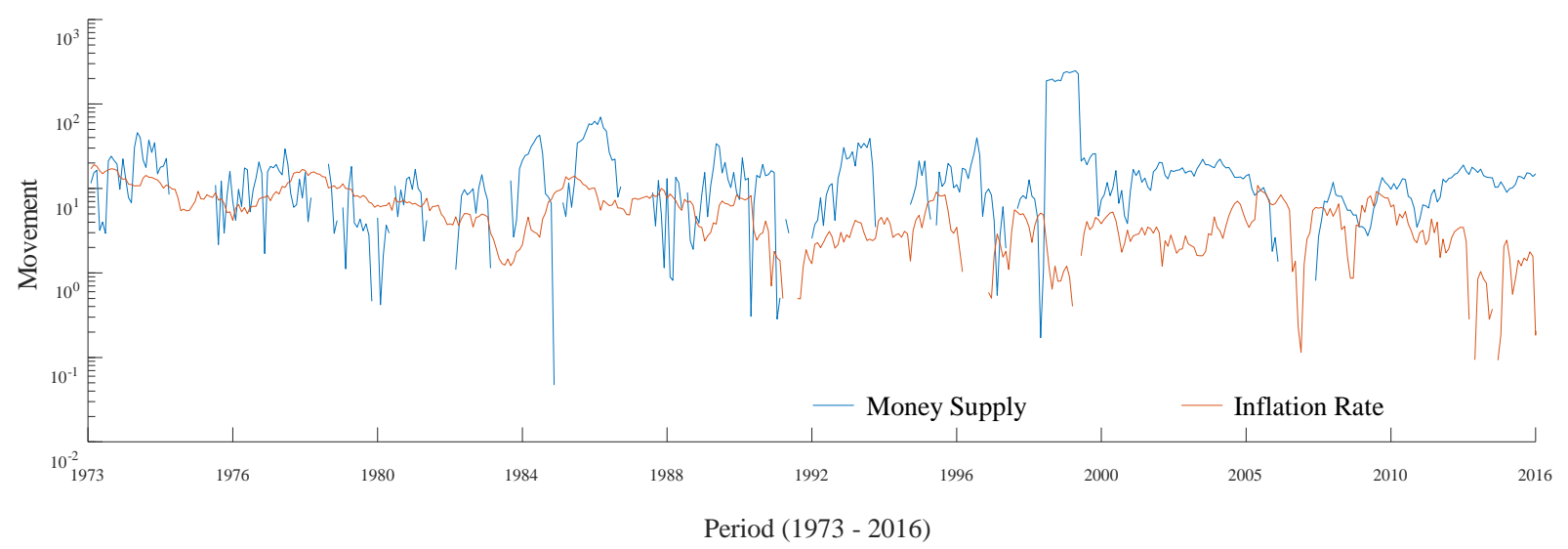

Figure 2. Fiji: Money supply \& inflation rate 
However, there are some outliers in money supply data. In 1987, the growth rate is the lowest as a result of political upheaval in Fiji during this year. The military coup by Sitiveni Rabuka and takeover of the government caused economic instability, thus a drop in money supply. This decrease in money supply resulted from decrease in domestic credit, as it was not that only the financial institution were not willing to lend money but individuals were also not prepared to borrow. Loss of investor confidence would lead to a decline in domestic credit. In addition to this, a decline in inflow of foreign funds will also impact money growth rate.

Also notably in 2000 , the broad money growth rate is abnormal. This was also impacted by political instability and takeover of government by coup leader George Speight.

Hence, with the understanding of above patterns of movement in broad money and inflation, we move further into developing a model for calculating inflation rate from growth in broad money.

The quarterly broad money data and CPI Index is plotted on a scatter graph to ascertain a model for calculating inflation rate from increase in money supply (Figure 3). CPI index is made up of basket of goods and this measures changes in prices of these goods and services in an economy. This basket of goods would be decided by the government or central bank and are generally key commodities of a country. Hence, in order to get a broader picture of price movement from wider range of goods and services, we use CPI Index data from 1973 to 2016.

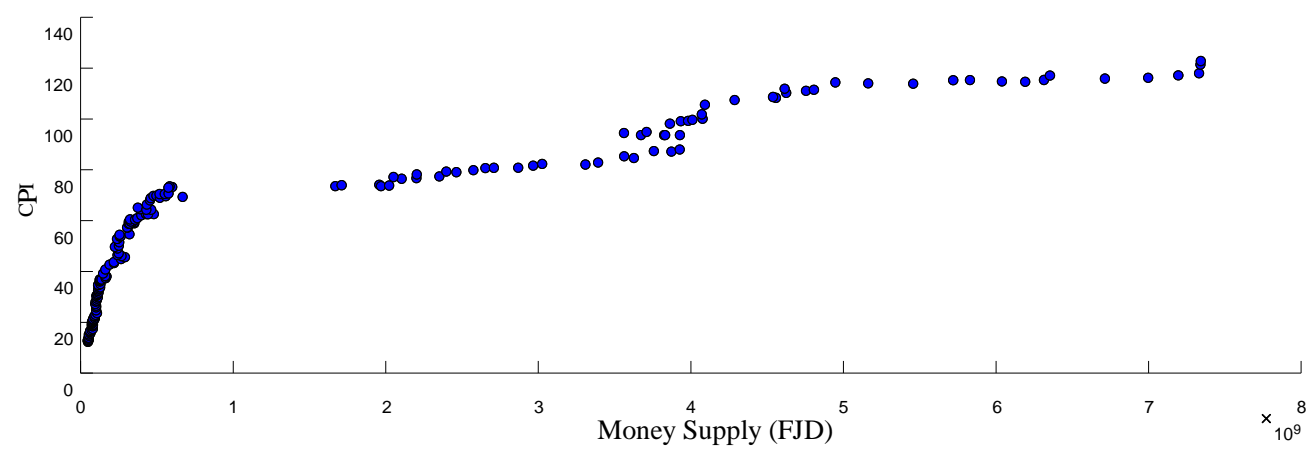

Figure 3. CPI \& money supply (1973-2016)

The scatter plot depicts a pattern in CPI movement and broad money. It is evident from above plot that as broad money ( $x$ axis) increases, the CPI (y axis) also increases. These two variables also reveal a pattern of exponential or growth with a variable having a power constant.

Thus, we use a line of fit to develop a model which can be used to forecast inflation rate using money supply data from SRF (Figure 4). This model is expected to forecast inflation rate with greater precision, given that it accommodates for a broader definition of money supply and this gives a more realistic view of how change in broad money will cause movement in price.

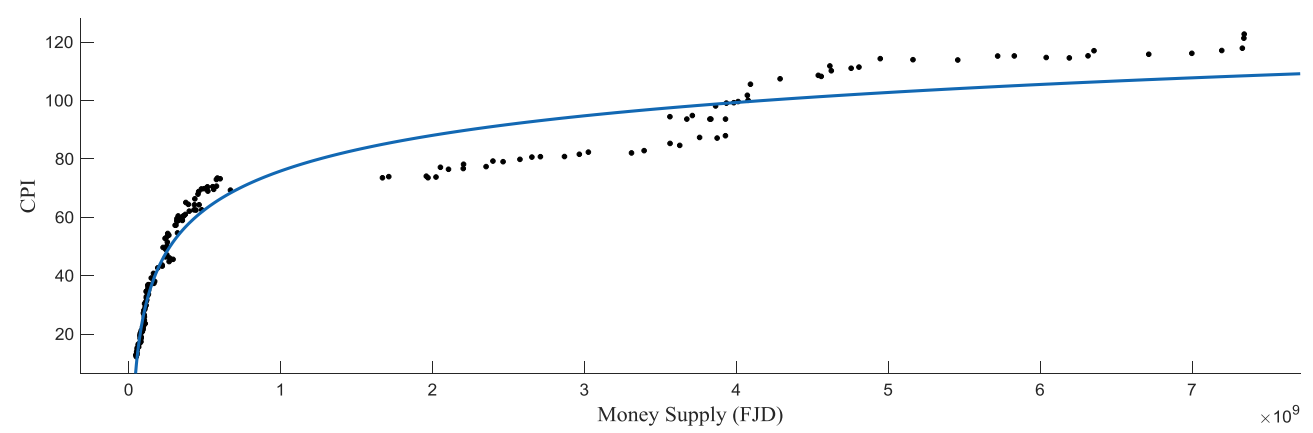

Figure 4. Money supply \& inflation model (1973-2016)

We draw the above line of fit and derive the following general power model.

$$
f(x)=a x^{b}+c
$$

The variables of this is model is defined and calculated as follows: 
$f(x)=$ Consumer Price Index $(y)$

$$
\begin{aligned}
& a=\frac{-c}{x^{b}} \\
& b=\frac{\frac{\log (y-c)}{a}}{\log (x)} \\
& c=\frac{-a}{x^{b}}
\end{aligned}
$$

The above line of fit and model has adjusted R-Square of 0.9532. This convinces that by use of above model, one can predict the value of Consumer Price Index. Knowing the value of Consumer Price Index will allow in calculation of inflation rate.

The use of non-standardised data for money supply is not anticipated to show such a strong correlation between broad money and consumer price index. This is simply because there will be under counting of broad money in an economy, since the survey results will not capture all financial players.

The policy makers can refer to this model and run relevant tests. This model will act as a tool for central banks and government in determining the increase in consumer price index due increase in money supply. This model can prevent a country from entering into scenarios of high inflation and even hyper-inflation from increases in broad money.

The central banks would also find this model useful while carrying out open market operations. In open market operations, the central banks sell and buy treasury bills or other local notes in order to control money supply. The central banks sell treasury notes to absorb excess money from the system and vice-versa. By running this model, the policy makers will be able to clearly calculate how much money they need to absorb from the system.

The model would also find its way in discussion and formulation of money policy. It is known from Equation 4 above that changes in domestic credit and net foreign assets leads to movement in money supply. As such, in order to control amount of money supply, the policy makers need to also consider controlling domestic credit via various monetary policy tools. Increase in domestic credit will lead to an increase in money supply and thus inflation, as depicted by above model (Equation 5). The policy makers need to calculate degree of movement in these variables very cautiously as to avoid situation of either high inflation or even zero inflation

\section{Conclusion}

A thorough analysis of broad money and inflation data revealed that these two variables move in same direction. An increase in broad money leads to an increase in consumer price index, which is a measure of inflation.

The model developed based on new standardised reporting format is powerful enough to provide a reliable estimation of inflation rate from available sets of broad money data. However, it is important to note that definition of broad money differs between countries.

Moreover, a further research on this can be carried out by considering how does natural disaster in a country impact consumer price index. Natural disaster such as cyclone, flood or drought also impacts prices of goods and services. Though it may be a challenge in getting a reliable set of data on these natural disaster, a model which would features such impacts will provide even a broader view of movement in price.

\section{References}

Amin, S. (2011). Quantity Theory of Money and its Applicability: The Case of Bangladesh. World Review of Business Research, 1, 33-43.

Denbel, F. S., Ayen, Y. W., \& Regasa, T. A. (2016). The Relationship between Inflation, Money Supply and Economic Growth in Ethiopia: Co integration and Causality Analysis. International Journal of Scientific and Research Publications, 6(1), 556-565.

Gatawa, N. M., Abdulgafar, A., \& Olarinde, M. O. (2013). Impact of Money Supply and Inflation on Economic Growth in Nigeria. Journal of Economics and Finance, 8(3), 26-37.

Gokal, V., \& Hanif, S. (2004). Relationship between Inflation and Economic Growth. Working Paper, Economics Department Reserve Bank of Fiji Suva Fiji, 2004/04. Retrieved from http://rbf.gov.fj/docs/2004_04_wp.pdf

International Monetary Fund. (2016). International Financial Statistics [CD-ROM]. Washington, NY: IMF.

International Monetary Fund. (2016). Monetary and Financial Statistics Manual and Compilation Guide. 
International Monetary Fund, Washington, D.C.

Koti, S., \& Bixho, T. (2016). Theories of Money Supply: The Relationship of Money Supply in a Period of Time T-1 and Inflation in Period T- Empirical Evidence from Albania. European Journal of Multidisciplinary Studies, 1(1). https://doi.org/10.26417/ejms.v1i1.p294-302

Mbongo, J. E., Mutasa, F., \& Msigwa, R. E. (2014). The Effects of Money Supply on Inflation in Tanzania. Economics Journal, 3(2), 19-26. https://doi.org/11648/j.eco.20140302.11

Mohammad, S. D., Wasti, S. K. A., Lal, I., \& Hussain, A. (2009). An Empirical Investigation between Money Supply, Government Expenditure, Output \& Prices: The Pakistan Evidence. European Journal of Economics, Finance and Administrative Sciences, (17).

Osakwe, J. O. (1983). Government Expenditure, Money Supply and Prices: 1970-1980. CBN Economic and Financial Review, 21(2), 23-42. https://doi.org/10.4236/me.2013.43018

Phillips, A. W. (1958). The Relationship between Unemployment and the Rate of Change of Money Wages in the United Kingdom 1861-1957. Economica, 25(100), 283-299. https://doi.org/10.2307/2550759

Shostak, F. (2017). The Connection between Money-Supply and Inflation. Retrieved from https://mises.org/blog/connection-between-money-supply-growth-and-inflation

Sinah, S. (2017). Empirical Evidence on Dynamics of Credit Growth and Foreign Reserve. Eurasian Journal of Economics and Finance, 5(3), 17-26. https://doi.org/10.15604/ejef.2017.05.03.002

Strano, A. (n. d). Money Supply and Inflation, How and how much can the Money Supply affect the Inflation Rate? Retrieved from https://www.ukdataservice.ac.uk/media/263125/strano-paper.pdf

Vaish, M. C. (2002). Macroeconomics Theory (11th ed.). New Delhi: UBS Publishers' PVT Ltd.

Vladova, Z., \& Yanchev, M. (2015). Empirical Evidence on the Relationship between Money Supply Dynamics and Prices in Bulgaria. Discussion Paper DP/100/2015.

\section{Copyrights}

Copyright for this article is retained by the author(s), with first publication rights granted to the journal.

This is an open-access article distributed under the terms and conditions of the Creative Commons Attribution license (http://creativecommons.org/licenses/by/4.0/). 